\title{
Record
}

\section{GENERAL MARTINI}

IT is with great regret that we announce the death, in Germany on 6 January, of General Wolfgang Martini, Executive Director of the Deutsche Gesellschaft für Ortung und Navigation. General Martini, who had a long and distinguished career in telecommunications and radio research, was elected an Honorary Member of this Institute in 1960 ; besides his service decorations he was one of the first officers of the former German Army to be awarded the Grand Service Cross of the Services Order of the Federal Republic of Germany. During the war, General Martini directed the Air Force Signal Corps, which produced the first German radar equipment. After the war, he became Director of the Ausschuss für Funkortung, which later became the Deutsche Gesellschaft für Ortung und Navigation. In this capacity he was responsible for much of the growth in international cooperation on a technical level in navigation, one result of which was the series of meetings sponsored jointly by the German society with this Institute and the French Institute of Navigation.

General Martini combined great intellectual vigour with a remarkably courteous approach, which one somehow knew to be real. It was an engaging mixture, and sometimes an amusing one, because for all his kindness he was not easily deflected. He inspired affection in all who had to do with him, not only in his own country but abroad, and he will be very much missed.

M.W.R.

\section{ADMIRAL OF THE FLEET SIR JOHN CUNNINGHAM}

Admiral of the Fleet Sir John Henry Dacres Cunningham, G.C.B., M.V.O., an Honorary Member of this Institute, died on 14 November 1962. He qualified as a Navigating Officer in 1906, and from then on had a most distinguished career, although seldom in the public eye. He was the first and only Navigating Officer to become First Sea Lord. During the Great War he served in the battleship Russell which was sunk in 1916, followed by appointments to the battle-cruiser Renown, where he was promoted to Commander in 1918 , and Lion, the flagship of the Grand Fleet. In I 9 I 8 he became the first navigator of the Hood and squadron navigator in the battle-cruiser squadron under Admiral Sir Roger Keyes. From 1921-3 he was commander at the Navigation School and then joined the Queen Elizabeth as Master of the Fleet until promoted to Captain in June 1924 .

Throughout his career as an active navigating officer he was always considered to be exceptional in all aspects of his trade, and his promotion to Admiral of the Fleet, coupled with his attainment of the highest appointment in the active service, were ample proof of his many other qualities. He continued to show a great interest in navigation, and particularly in the Navigation and Direction School at H.M.S. Dryad, where he regularly attended the Annual Dinner.

During the late war he seldom came to the public eye, but he had his full share of arduous responsibility. In the Mediterranean he was responsible for the taking of Elba, the Anzio landing, and the invasion of Southern France. His true worth 